\title{
Building Research into Undergraduate Curricula: Georgia College \& State University Moves Full STEAM Ahead
}

\begin{abstract}
In 2009, interested faculty and staff members at Georgia College \& State University (GCSU) initiated an effort to promote mentored undergraduate research (UR) and creative endeavors on campus. As the planning group expanded and more faculty and students became involved in mentored UR, the goal of the group evolved into getting the university administration to recognize UR as an integral and legitimate part of the university's liberal arts mission. The following describes the success of those efforts and includes two case studies showing the use of planning and implementation grants to restructure curricula in disciplines as diverse as environmental science and theatre programs.
\end{abstract}

In 2009, a small planning group of faculty and staff at Georgia College \& State University (GCSU) started a grassroots effort to promote mentored undergraduate research (UR) and creative activities at the institution. As the membership of this planning group grew and more faculty and students engaged in mentored UR, the goal of the group evolved into getting the university administration to recognize UR as an integral and legitimate part of the university's liberal arts mission. In 2012, the administration provided funding and a space for what is now known as MURACE-the Mentored Undergraduate Research and Creative Endeavors program. Since its inception, the MURACE program has fostered UR by providing funding for departmental planning and implementation grants, summer research grants for students and their mentors, and travel grants to students for conference presentations.

To increase campus awareness of undergraduate research and the opportunities available, MURACE offers two symposia each year, as well as participates in several other conferences. These include the Georgia Undergraduate Research Conference (GURC); the Georgia College Student Research Conference; the Council of Public Liberal Arts (COPLAC) Regional UR Conference; and the National Council of Undergraduate Research (NCUR) conference. Many of our students also present each year at national and international conferences where the scholarly presentations are peerreviewed.

Through financial and logistical support, MURACE has contributed to an institutional culture of excitement and enthusiasm for undergraduate research and creative endeavors.



GCSU environmental science students in the Applied Hydrogeology research course investigating factors associated with crayfish distribution on Sapleo Island, GA.

Our MURACE programs demonstrate to faculty, students, and administrators across campus that the institution values undergraduate research experiences in all disciplines. By bringing together faculty from the sciences and the arts to formulate shared strategies, we have built an interdisciplinary framework for undergraduate research supported by our liberal arts mission.

Although all MURACE programs are important to UR, the initial planning group determined that departmental planning and implementation grants would have the greatest potential for institutionalizing UR across the curriculum. Here we highlight the role of MURACE as a facilitator of planning and implementation of quality UR experiences for the greatest number of undergraduates, focusing on two departments that have been very successful in incorporating UR into their curricula.

\section{Why Focus on Departments and Programs?}

There is a tendency in academic culture for faculty members to work in relative isolation from their colleagues, even when individual faculty members are developing and implementing innovative pedagogies and curricula. Following the reasoning of Wergin (2003), our goal was to move faculty members from ad hoc, individualized work to shared, collaborative work by providing support to departments that require faculty to engage in shared planning for the integration of UR across the curriculum. 




Summer scholar Leah Dannenberg explains her summer research project at the Fall 2015 MURACE Symposium.

Under favorable circumstances, academic departments and programs can drive institutional-level change and curricular reform (Saltmarsh and Gelmon 2006; Lee, Hyman, and Luginbuhl 2007). Given that our long-term goal is to institutionalize UR across the curriculum, not just in general education, but across the majors as well, we see the integration of UR within individual departments and programs as a strategy for providing models of change for skeptical academic units. The fact that we have models from both the hard sciences and the humanities belies the argument that UR is better suited to some disciplines than to others.

Another reason for highlighting academic departments and programs is that several departments on campus were ready to advance UR as a core component of their students' educational experiences. Lee et al. (2007) defined readiness as the "degree to which existing conditions within the department are conducive to change" (5). The work done by the initial UR planning group, the existing support for the annual student research conference, and our two undergraduate research journals had created a climate of "readiness" for UR in several departments. Some departments just needed a few additional resources and time to build on outstanding undergraduate research opportunities that were already in place but that had not been integrated cohesively within the departments.

Besides their being able to drive institutional change, providing resources to departments and programs for the integration of UR across the curriculum engages faculty in the process of continuous quality improvement relative to curricular planning (Briggs, Stark, and Rowland-Poplawski 2003). As the case studies here demonstrate, the planning and implementation grants allowed the faculty members involved to plan, assess, and reflect on their changes and to make appropriate adjustments.
Finally, focusing on integrating UR at the departmental level allows the departments to scaffold undergraduate research across courses from the first year to the final year (frequently resulting in capstone research projects) and allows students to experience multiple models of undergraduate research. In a study of how research opportunities were embedded in the curriculum of a large, research-intensive university in Australia, Zimbardi and Myatt $(2014,239)$ identified five models for undergraduate research:

1. the "apprenticeship" model, in which "students work under the direct supervision of an academic staff member in an area related to the academic's current research or expertise;"

2. the "industry project" model, in which "students focus on a complex problem they are likely to encounter in their profession;"

3. the "inquiry project" model, in which "students undertake the entire research process with a focus on learning disciplinary content and processes of knowledge production;"

4. the "methods course" model, in which "students engage in truncated versions of the research process, with a focus on a broad range of methodological processes commonly used in the discipline;" and

5. the "mixed model" that combines features of two or more of the above.

Here we provide two case studies that demonstrate the true commitment of our university to implement UR in both the arts and sciences and the dedication of our faculty to creating innovative programs to reach the greatest number of undergraduates. Undergraduates in both cases participated in multiple types of research activities that conform to the models outlined above. Although it is possible for students to experience one or more of these models within majors lacking the coherence and continuity provided by our departmental curricular planning and implementation grants, those experiences likely would be ad hoc and disconnected for the student.

\section{Planning and Implementation Grants}

The criteria for GCSU planning and implementation grants were created and updated by a volunteer committee made up of faculty and staff representing several disciplines. The selection process for these grants is highly competitive. Proposals are reviewed by a faculty committee in the spring with funds for winners awarded at the beginning of July of the same year. Grant recipients report their activities and accomplish- 
ments through a written report and a presentation at the annual symposium in the spring semester of the year following their grant awards.

Planning grants (typically two per academic year) of up to $\$ 5,000$ are used to analyze a department or program's strengths and weaknesses in undergraduate research and to create an action plan for institutionalizing UR within the program or department. To be eligible for a planning grant, departments or programs must be in the initial stages of integrating UR across the curriculum. Some stipulations for successful proposals include: (1) providing a timeline of activities; (2) explaining how the proposed work will impact student-learning outcomes and help build a foundation for student research; 3) identifying how the proposed work will align with the objectives of the Association of American Colleges \& Universities' (AAC\&U) Valid Assessment of Learning in Undergraduate Education (VALUE) rubrics; (4) identifying key project participants and the rationale for their selection; (5) identifying anticipated outcomes and action steps; (6) describing how the plan will be sustainable; (7) explaining how the plan will be evaluated and disseminated; and 98) providing a budget and budget narrative. A department or program successful in obtaining a planning grant is expected to apply for an implementation grant the following year.

Implementation grants of up to $\$ 7,500$ (typically one per academic year) are available to programs or departments that propose clear and assessable implementation plans. The paramount goal of this grant is to institutionalize UR by providing student projects that are responsive to students' needs for a foundation in research and a progressive curriculum that integrates UR throughout their college careers. To be eligible for an implementation grant, departments or programs must have earlier received a planning grant or provided a plan of equal quality, meeting all of the requirements for the planning grants that were outlined above.

Some stipulations for receiving the implementation grants include: (1) providing a statement of purpose identifying the impact that the department or program intends to accomplish through the project; (2) including a rationale for why the project is important; (3) providing a project overview; (4) identifying key project objectives; (5) identifying anticipated ancillary outcomes beyond key objectives; (6) describing the project activities that should lead to accomplishment of key objectives; (7) providing information about the program's or department's track record in UR; (8) providing a project evaluation plan; (9) explaining how the project will be sustained after the funding period; (10) providing an implementation timeline; and (11) providing a budget and a budget narrative.

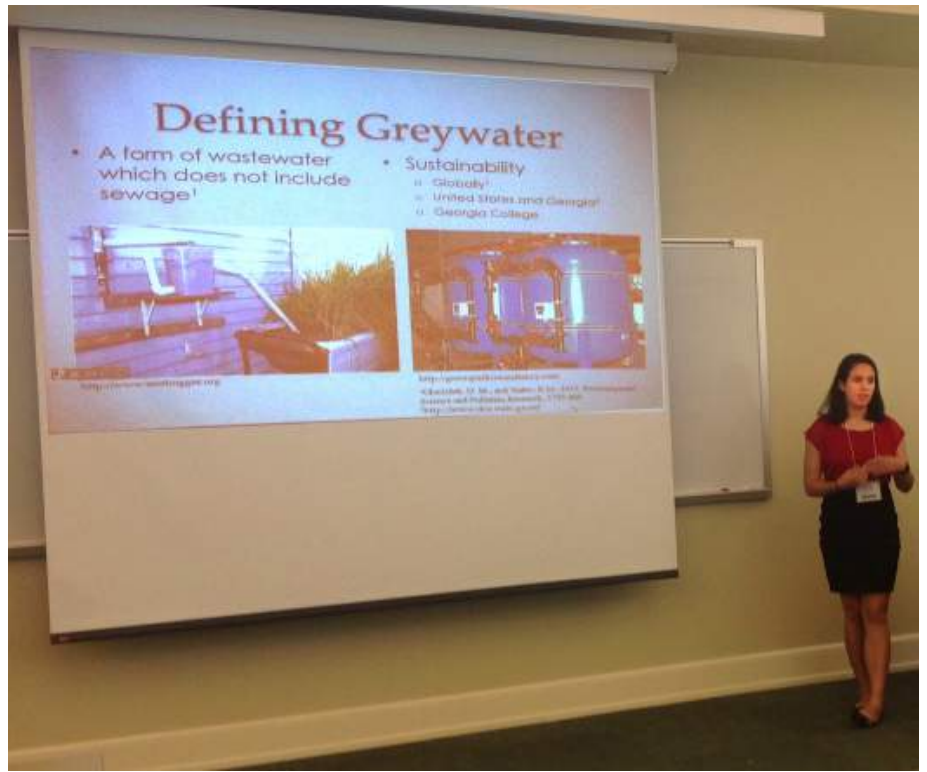

Environmental science major Mary Plauche presenting her research at NCUR 2016

\section{Case Studies}

Over two years, supported by MURACE planning and implementation grants, the environmental science and theatre programs have restructured their curricula so that all students experience undergraduate research. These two very different disciplines are highlighted as case studies to demonstrate how GCSU departments and programs successfully build research experiences into their curricula. Faculty in both programs acted at the curriculum level to ensure that all students within each program had research opportunities. Both programs created and redesigned courses and provided substantial support for students to make presentations at state, regional, and national conferences. Students from these programs have made original intellectual and creative contributions through their conference participation. In addition, several graduates of both programs have corresponded with their mentors to let them know the value of their undergraduate research experiences in preparing them for careers or graduate programs. Their reports are in line with the findings of Searight, Ratwick, and Smith (2010) who found direct links between students' UR experiences and post-graduation success.

\section{Environmental Science Case Study}

The relatively small, young environmental science program features UR as a major strength, and significant portions of its students participate. Of the 15 students who graduated 
in May 2015, 80 percent reported that they had participated in at least one course-based UR experience, and 60 percent reported that they had participated in at least one UR experience outside of the classroom (either independent research on campus or elsewhere). All environmental science faculty mentor undergraduates and are strong supporters of UR. Students receive the benefits associated with UR participation, including increased understanding of the scientific method, confidence in their own abilities, and awareness of graduate school requirements (Lopatto 2007; Russell, Hancock, and McCullough 2007).

Over the past three years, the program has revised its curriculum to scaffold course-based UR opportunities throughout. This work was initially supported by a MURACE planning grant in 2014, and the program is currently supported by a MURACE implementation grant. The program began the curriculum revision by examining its desired student-learning outcomes (SLOs) and then building a curriculum map to illustrate how its various courses supported the outcomes (Uchiyama and Radin 2009; Zelenitsky et al. 2014). Program faculty then moved on to specific program revisions, including replacing and revising courses. Faculty members decided to focus on building UR experiences directly into courses in order to reach more students and better align coursework with the program's desired outcomes for students (Lopatto 2007; Russell et al. 2007).

As part of curriculum revisions, faculty proposed three new required courses and revised the introductory laboratory course to include an inquiry-guided group research project. In the new lab course, students work in groups over six weeks to design an experiment that addresses an environmental science question, implement the experiment, and present their results in both oral and written formats. The program implemented the new inquiry labs for the first time in ten lab sections during the fall 2014 term. The initial feedback from students, both majors and non-majors, indicated excitement about having their own projects, but they also expressed frustration with the open-ended and indeterminate nature of the research.

For sophomores, the program will introduce a new research methods course to introduce them to research basics such as using common research instruments, writing a research proposal, entering and analyzing data in a spreadsheet, and presenting results. Including these skills in a 2000-level course is designed to enable students to start future research projects equipped with these basic skills. This course also introduces students to research opportunities, introducing them to research faculty in the program. In addition, upper-division students present their research projects and



Student Shannon Stephenson explains her research to faculty members at the 2016 GCSU Student Research Conference.

provide information on getting involved in research to their sophomore peers. The program faculty also designed another course, Environmental Problems \& Sustainable Solutions, in response to students' calls for additional project-based courses in the curriculum. This course, which will support multiple desired student outcomes, will be offered for the first time in spring 2017.

For seniors, program faculty added a new research capstone course, which brings together all seniors in environmental science who are conducting independent research. Students write proposals focused on fulfilling the criteria to apply for a National Science Foundation (NSF) Graduate Research Fellowship, give presentations, write reports, and discuss primary literature. This course benefits students by giving them an opportunity to interact with other undergraduate researchers in the ENSC program and to receive feedback from an instructor other than their mentor. This class allows discussions of current literature and student collaboration in solving common problems associated with independent research projects.

As the faculty move forward with the new curriculum, they will assess the program by evaluating students' research skills and observing how many students present their research at scientific conferences. They expect to see an increase in students' ability to correctly design experiments, analyze data, and present scientific information. The faculty also will continue to solicit feedback from students and instructional faculty to determine how to best support UR within the environmental science program. 
Integrating UR across the curriculum is not only an effective strategy for science, technology, engineering, and mathematics (STEM) disciplines, it is also a powerful pedagogy for humanities disciplines. Consequently, MURACE's approach to integrating UR at the departmental level allows the university to move beyond a STEM focus to a science, technology, engineering, arts, and mathematics (STEAM) focus. Some examples include:

- Theatre for Social Change, which is a general-education course that involves collaboration between the Department of Theatre and Dance and the School of Nursing. Undergraduate research conducted on teen suicide, teen pregnancy, HIV/AIDS, and other health topics results in student-written plays that theatre students perform for at-risk teens. This interdisciplinary work is a hallmark of the undergraduate experience at GCSU.

- The production of the play "Miss Electricity," involving undergraduate research in both the theatre department and the Science Education Center. Undergraduates in theatre researched the play and performed it for school children as part of their creative scholarship. Students studying environmental science prepared the research and lesson plans about the play sent out to elementaryschool children in multiple counties. An electric car was provided for the audiences to touch as part of the performance. The Science Education Center under Dr. Rosalie Richards oversaw the GCSU students who prepared the $\mathrm{K}-12$ teacher lesson plans for teachers to supplement their experience at GCSU inside their own classrooms.

- The Fats, Oil, and Grease (FOG) Project, in which undergraduate students in marketing, environmental science, and theatre conducted collaborative research about the disposal of these materials to develop an original play, "Don't Flush It," as part of a campus environmental symposium.

While faculty members in environmental science have made every attempt to increase UR in their program, they still struggle to provide all students in the program with UR outside of the classroom, particularly independent research mentored by faculty. In order to obtain employment and/ or admission to graduate school in the field, graduates from the environmental sciences program are expected to have current scientific knowledge, research experience, and the ability to communicate scientific findings and information. While independent, faculty-mentored research is the "gold standard" for achieving these outcomes, faculty, as noted, have also sought through the program revision to provide students these opportunities in a classroom-based setting. This program revision has been a long, time-consuming process, but it has been facilitated by the cooperative nature and

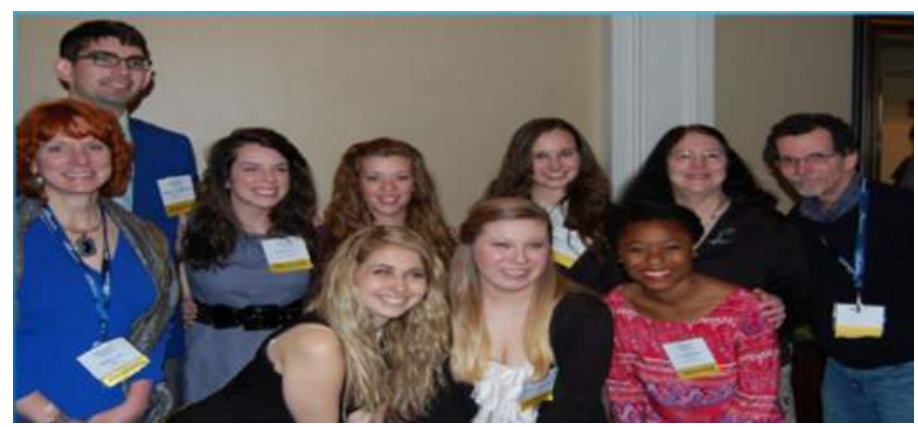

Drs. Sallie Coke and Karen Berman with students from the Nursing/Theatre/ Early College Collaboration and Dr. Steve Jones at the Gulf-South Summit on Service Learning and Civic Engagement Through Higher Education in Auburn, Alabama.

dedication of the environmental science curriculum committee and the support structure at the university.

As faculty members continue to implement and adapt the revisions, another challenge has been finding a good balance between the process of evaluation and improvement and providing continuity for students. While continuously asking for student feedback regarding their own progress in the inquiry-guided labs, we also seek balance in terms of using student feedback data productively, without implementing too many changes year-to-year. We have found that implementing too many changes is both exhausting for us and frustrating for students. We also have found that changes as significant as the ones we have described sometimes take a number of years to implement fully.

\section{Theatre Department Case Study}

With MURACE funding, faculty members in the Department of Theatre and Dance have been incorporating research opportunities and requirements in courses from the first year through the senior capstone project. While research has always been an integral part of theatre, the grants from MURACE have greatly increased students' awareness of opportunities to share their work beyond the classroom. After planning and implementing undergraduate research through deliberate scaffolding, a key component in creating a UR culture in the department has been continued and consistent participation in the GCSU Student Research Conference, now in its 19th year. The close faculty mentorship developed for student presentations at conferences, has helped the department to sustain students' enthusiasm and, perhaps even more importantly, maintain the regular habit of presenting. By participating in the conference, the department's students share their research with between 200 and 300 students from 27 different departments. Faculty members also help students present at state, national, and even 
international events through deliberate scaffolding within our curriculum and also within presentation expectations. Maintaining an effective, structured path to presentation is not sustainable without MURACE funding and support.

\section{Assessing UR in Theatre}

What has been the impact of incorporating undergraduate research throughout our theatre and dance programs? The department addressed that question by identifying specific learning outcomes and appropriate assessment tools to measure the impact of UR on those outcomes. Department faculty members developed a single assessment rubric based on learning outcomes identified in the Association of American Colleges \& Universities' (AAC\&U) Valid Assessment of Learning in Undergraduate Education (VALUE) rubrics. The AAC\&U's VALUE rubrics are described as "the most common and broadly shared criteria or core characteristics that are considered critical for judging the quality of student work" (Maki 2015, 17). In our modified rubric, we selected specific outcomes from the following VALUE rubrics, including quotes regarding desired student outcomes from the AAC\&U document.

The specific outcomes assessed are:

Diversity of communities and cultures: The student "Demonstrates evidence of adjustment in own attitudes and beliefs because of working within and learning from diversity of communities and cultures. Promotes others' engagement with diversity." (AAC\&U Civic Engagement VALUE Rubric)

- Connecting, synthesizing, and transforming: The student "Transforms ideas or solutions into entirely new forms." (Creative Thinking VALUE Rubric)

- Critical position-taking: The student's "Specific position (perspective, thesis/hypothesis) is imaginative, taking into account the complexities of an issue. Limits of position are acknowledged. Others' points of view are synthesized within position." (Critical Thinking VALUE Rubric)

- Ethical self-awareness: "Student discusses in detail/analyzes both core beliefs and the origins of the core beliefs and discussion has greater depth and clarity." (Ethical Reasoning VALUE Rubric)

- Personal and social responsibility: The student "Takes informed and responsible action to address ethical, social, and environmental challenges in global systems and evaluates the local and broader consequences of individual and collective interventions." (Global Learning VALUE Rubric)
- Use of information to accomplish purpose: The student "Communicates, organizes and synthesizes information from sources to fully achieve a specific purpose, with clarity and depth." (Information Literacy VALUE Rubric)

- Design process: Students' research or creative work demonstrates that "All elements of the methodology or theoretical framework are skillfully developed. Appropriate methodology or theoretical frameworks may be synthesized from across disciplines or from relevant subdisciplines." (Inquiry and Analysis VALUE Rubric)

- Connections to experience: The student "Meaningfully synthesizes connections among experiences outside of the formal classroom (including life experiences and academic experiences such as internships and travel abroad) to deepen understanding of fields of study and to broaden own points of view." (Integrative Learning VALUE Rubric)

- Empathy: The student "Interprets intercultural experience from the perspectives of more than one worldview and demonstrates ability to act in a supportive manner that recognizes the feelings of another cultural group." (Intercultural Knowledge VALUE Rubric)

- Independent learning: The student's "Educational interests and pursuits exist and flourish outside classroom requirements. Knowledge and/or experiences are pursued independently." (Lifelong Learning VALUE Rubric)

- Communicating central message: The student expresses a "Central message [that] is compelling (precisely stated, appropriately repeated, memorable, and strongly supported.)" (Oral Communication VALUE Rubric)

- Implementing a solution: The student "Implements the solution in a manner that addresses thoroughly and deeply multiple contextual factors of the problem." (Problem-Solving VALUE Rubric)

- Communication: The student "Uses quantitative information in connection with the argument or purpose of the work, presents it in an effective format, and explicates it with consistently high quality." (Quantitative Literacy VALUE Rubric)

- Interpretation: The student "Provides evidence not only that $\mathrm{s} / \mathrm{he}$ can read by using an appropriate epistemological lens but that $\mathrm{s} / \mathrm{he}$ can also engage in reading as part of a continuing dialogue within and beyond a discipline or a community of readers." (Reading VALUE Rubric) 
- Contributing to team meetings: The student "Helps the team move forward by articulating the merits of alternative ideas or proposals." (Teamwork VALUE Rubric)

- Genre and disciplinary conventions: The student "Demonstrates detailed attention to and successful execution of a wide range of conventions particular to a specific discipline and/or writing task(s) including organization, content, presentation, formatting, and stylistic choices." (Written Communication Rubric)

The faculty members selected these particular outcomes based on shared expectations of the skills we want to see in our graduating students. In addition, the VALUE rubrics served the objective that "a student learning outcome [be] a concise statement of precisely what a student is expected to know, understand, or be able to do as a result of the goals that your program has adopted" (Buller 2012, 355).

The assessment criteria used by the VALUE rubrics to evaluate students' work range from "benchmark," which is the lowest acceptable level of work or performance, to the "capstone," which is the highest level of achievement. For each of the courses in which we evaluated the impact of undergraduate research on these outcomes, students were required to maintain a course portfolio containing specific assignments and students' reflections on their assignments. The rubric was applied as a holistic evaluation of the portfolio.

Table 1 shows the results of our assessments following the first year of the implementation grant. When combining all of the 16 assessed categories, 46.2 percent of theatre and dance students whom we assessed achieved the capstone level based on our rubric and 15.4 percent were below the benchmark level. Achievement was highest for the lifelong learning, teamwork, and creative thinking outcomes. Student achievement was lowest for the quantitative literacy outcome; only 13 percent reached the capstone level and 44.2 percent failed to attain the benchmark level. Through use of the assessment rubric, faculty members acquired "evidence of students' strength and patterns of underperformance" and subsequently made adjustments to course assignments and activities (Maki 2015, 41-42).

Faculty members utilized these initial student assessment results to revise the curriculum and improve their mentoring skills as they became fully committed to making mentoring of undergraduate researchers a priority. Mentoring undergraduate researchers became an integral part of the responsibility of faculty members, and one-on-one mentoring became an important part of each faculty member's schedule. With the department's MURACE funding, students quickly became excited about undergraduate research as word spread about the value of presenting at conferences. Students returning from conferences shared their achievements and communicated a newfound pride in their work. Furthermore, the students developed a more sophisticated understanding of the craft and preparation needed for successful undergraduate research.

Following the second year of the grant, and the refinements of courses and activities made by the faculty, a total of 83 theatre students were evaluated using the rubric. Further, 48 students were evaluated separately for their work in a general-education course, Theatre as Social Change, offered by theatre faculty members. Twenty-three dance students were also evaluated on dance research and original creative work. In certain cases, students researched multiple projects. Therefore, the department evaluated the impact of undergraduate research activities on student learning for total of 154 students.

As Table 2 shows, assessment after the second year of implementation showed tremendous improvement in students' results. When combining all of the 16 assessed categories, 57.5 percent of theatre and dance students reached the capstone level, based on the rubric, and none were below the benchmark level. Student results based on the VALUE rubrics were highest for the creative and critical thinking, integrative learning, lifelong learning, oral communication, and teamwork desired outcomes. Furthermore, the percentage of students reaching the capstone level in quantitative literacy increased from 13 percent after the first year to 42 percent after the second year. Expectations became more apparent to students, and theatre and dance professors became more accomplished at mentoring undergraduate research.

Integrating undergraduate research into the curriculum ensures that students have the opportunity to participate in a research experience. Integration of UR does not come without its hurdles, however. Multiple exposures to research opportunities within the curriculum cannot assure that every student completes his or her research requirements or attends a conference. The learning experience does not come without the potential for misunderstanding between students from different disciplines. For example, a theatre student may not understand the research expectations of students in the nursing program. Nursing students may be surprised to learn that theatre students expect them to "practice" at midnight for a presentation.

\section{Discussion}

Additional funding to integrate UR into the curriculum and to provide students opportunities to present their research at national conferences comes at a cost. The theatre department relied on nearly $\$ 12,000$ in grant funding from the MURACE program. Whether dissemination of undergraduate research is possible without such grants is uncertain. Faculty members' workloads also have grown due to additional as- 
Table 1. First-Year Student Assessment Using AAC\&U* VALUE Sample Rubrics for Theatre, Dance, and Theatre as Social Change Undergraduate Research

\begin{tabular}{|c|c|c|c|c|c|c|}
\hline CIVIC ENGAGEMENT VALUE RUBRIC & $\begin{array}{c}\text { Capstone } \\
4\end{array}$ & $\begin{array}{c}\text { Milestone } \\
3\end{array}$ & $\begin{array}{c}\text { Milestone } \\
2\end{array}$ & \begin{tabular}{|c|} 
Benchmark \\
$1^{\star * \star}$
\end{tabular} & & Total ${ }^{* *}$ \\
\hline Diversity of Communities and Cultures & 82 & 48 & 39 & 0 & 46 & 215 \\
\hline CREATIVE THINKING VALUE RUBRIC & $\begin{array}{c}\text { Capstone } \\
4\end{array}$ & $\begin{array}{c}\text { Milestone } \\
3\end{array}$ & $\begin{array}{c}\text { Milestone } \\
2\end{array}$ & \begin{tabular}{|c|} 
Benchmark \\
1
\end{tabular} & & Total \\
\hline Connecting, Synthesizing, \& Transforming & 132 & 58 & 22 & 3 & 0 & 215 \\
\hline CRITICAL THINKING VALUE RUBRIC & $\begin{array}{c}\text { Capstone } \\
4\end{array}$ & $\begin{array}{c}\text { Milestone } \\
3\end{array}$ & $\begin{array}{c}\text { Milestone } \\
2\end{array}$ & $\begin{array}{c}\text { Benchmark } \\
1\end{array}$ & & Total \\
\hline Critical Position-Taking & 120 & 78 & 15 & 2 & 0 & 215 \\
\hline ETHICAL REASONING VALUE RUBRIC & $\begin{array}{c}\text { Capstone } \\
4\end{array}$ & $\begin{array}{c}\text { Milestone } \\
3\end{array}$ & $\begin{array}{c}\text { Milestone } \\
2\end{array}$ & \begin{tabular}{|c|} 
Benchmark \\
1
\end{tabular} & & Total \\
\hline Ethical Awareness & 80 & 36 & 32 & 1 & 66 & 215 \\
\hline GLOBAL LEARNING VALUE RUBRIC & $\begin{array}{c}\text { Capstone } \\
4\end{array}$ & $\begin{array}{c}\text { Milestone } \\
3\end{array}$ & $\begin{array}{c}\text { Milestone } \\
2\end{array}$ & \begin{tabular}{|c|} 
Benchmark \\
1
\end{tabular} & & Total \\
\hline Personal \& Social Responsibility & 60 & 60 & 33 & 16 & 46 & 215 \\
\hline INFO LITERACY VALUE RUBRIC & $\begin{array}{c}\text { Capstone } \\
4 \\
\end{array}$ & $\begin{array}{c}\text { Milestone } \\
3 \\
\end{array}$ & $\begin{array}{c}\text { Milestone } \\
2 \\
\end{array}$ & $\begin{array}{c}\text { Benchmark } \\
1 \\
\end{array}$ & & Total \\
\hline Use of Information to Accomplish Purpose & 50 & 48 & 32 & 9 & 76 & 215 \\
\hline INQUIRY \& ANALYSIS VALUE RUBRIC & $\begin{array}{c}\text { Capstone } \\
4 \\
\end{array}$ & $\begin{array}{c}\text { Milestone } \\
3 \\
\end{array}$ & $\begin{array}{c}\text { Milestone } \\
2 \\
\end{array}$ & \begin{tabular}{|c|} 
Benchmark \\
1 \\
\end{tabular} & & Total \\
\hline Design Process & 108 & 53 & 44 & 9 & 1 & 215 \\
\hline INTEGRATIVE LEARNING VALUE RUBRIC & $\begin{array}{c}\text { Capstone } \\
4\end{array}$ & $\begin{array}{c}\text { Milestone } \\
3\end{array}$ & $\begin{array}{c}\text { Milestone } \\
2\end{array}$ & \begin{tabular}{|c|} 
Benchmark \\
1
\end{tabular} & & Total \\
\hline Connections to Experience & 121 & 75 & 17 & 2 & 0 & 215 \\
\hline INTERCULTURAL KNOWLEDGE RUBRIC & $\begin{array}{c}\text { Capstone } \\
4\end{array}$ & $\begin{array}{c}\text { Milestone } \\
3\end{array}$ & $\begin{array}{c}\text { Milestone } \\
2\end{array}$ & \begin{tabular}{|c|} 
Benchmark \\
1
\end{tabular} & & Total \\
\hline Empathy & 121 & 36 & 38 & 13 & 7 & 215 \\
\hline LIFELONG LEARNING VALUE RUBRIC & $\begin{array}{c}\text { Capstone } \\
4\end{array}$ & $\begin{array}{c}\text { Milestone } \\
3\end{array}$ & $\begin{array}{c}\text { Milestone } \\
2\end{array}$ & \begin{tabular}{|c|} 
Benchmark \\
1
\end{tabular} & & Total \\
\hline Independent Learning & 143 & 52 & 17 & 3 & 0 & 215 \\
\hline ORAL COMMUNICATION RUBRIC & $\begin{array}{c}\text { Capstone } \\
4 \\
\end{array}$ & $\begin{array}{c}\text { Milestone } \\
3 \\
\end{array}$ & $\begin{array}{c}\text { Milestone } \\
2 \\
\end{array}$ & $\begin{array}{c}\text { Benchmark } \\
1\end{array}$ & & Total \\
\hline Communicating Central Message & 95 & 45 & 8 & 0 & 67 & 215 \\
\hline PROBLEM-SOLVING VALUE RUBRIC & $\begin{array}{c}\text { Capstone } \\
4\end{array}$ & $\begin{array}{c}\text { Milestone } \\
3\end{array}$ & $\begin{array}{c}\text { Milestone } \\
2\end{array}$ & \begin{tabular}{|c|} 
Benchmark \\
1
\end{tabular} & & Total \\
\hline Implementing a Solution & 118 & 36 & 50 & 3 & 8 & 215 \\
\hline QUANTITATIVE LITERACY RUBRIC & $\begin{array}{c}\text { Capstone } \\
4\end{array}$ & $\begin{array}{c}\text { Milestone } \\
3\end{array}$ & $\begin{array}{c}\text { Milestone } \\
2\end{array}$ & \begin{tabular}{|c|} 
Benchmark \\
1
\end{tabular} & & Total \\
\hline Communication & 28 & 72 & 17 & 3 & 95 & 215 \\
\hline READING VALUE RUBRIC & $\begin{array}{c}\text { Capstone } \\
4\end{array}$ & $\begin{array}{c}\text { Milestone } \\
3\end{array}$ & $\begin{array}{c}\text { Milestone } \\
2\end{array}$ & \begin{tabular}{|c|} 
Benchmark \\
1
\end{tabular} & & Total \\
\hline Interpretation & 120 & 30 & 11 & 2 & 52 & 215 \\
\hline TEAMWORK VALUE RUBRIC & $\begin{array}{c}\text { Capstone } \\
4 \\
\end{array}$ & $\begin{array}{c}\text { Milestone } \\
3 \\
\end{array}$ & $\begin{array}{c}\text { Milestone } \\
2 \\
\end{array}$ & $\begin{array}{c}\text { Benchmark } \\
1\end{array}$ & & Total \\
\hline Contributing to Team Meetings & 145 & 61 & 7 & 2 & 0 & 215 \\
\hline WRITTEN COMMUNICATION RUBRIC & $\begin{array}{c}\text { Capstone } \\
4\end{array}$ & $\begin{array}{c}\text { Milestone } \\
3\end{array}$ & $\begin{array}{c}\text { Milestone } \\
2 \\
\end{array}$ & \begin{tabular}{|c|} 
Benchmark \\
1
\end{tabular} & & Total \\
\hline Genre and Disciplinary Conventions & 67 & 46 & 35 & 0 & 67 & 215 \\
\hline
\end{tabular}

*AAC\&U refers to Association of American Colleges and Universities. Levels of student attainment range from "benchmark" to "capstone" with capstone being the highest level of student achievement.

** Total number of students assessed appears as "Total" on the right of each rubric.

*** Numbers to right of "benchmark 1" are scores below benchmark criteria. 
Table 2. Second-Year Student Assessment Using AAC\&U* VALUE Sample Rubrics for Theatre, Dance, and Theatre as Social Change Undergraduate Research

\begin{tabular}{|c|c|c|c|c|c|c|}
\hline CIVIC ENGAGEMENT VALUE RUBRIC & $\begin{array}{c}\text { Capstone } \\
4\end{array}$ & $\begin{array}{c}\text { Milestone } \\
3\end{array}$ & $\begin{array}{l}\text { Milestone } \\
2\end{array}$ & \begin{tabular}{|c|} 
Benchmark \\
$1^{\star * \star}$
\end{tabular} & & Total** \\
\hline $\begin{array}{l}\text { Civic Identity and Commitment (Diversity } \\
\text { of Communities and Cultures) }\end{array}$ & 79 & 51 & 21 & 3 & 0 & 154 \\
\hline CREATIVE THINKING VALUE RUBRIC & $\begin{array}{l}\text { Capstone } \\
4\end{array}$ & $\begin{array}{l}\text { Milestone } \\
3\end{array}$ & $\begin{array}{l}\text { Milestone } \\
2\end{array}$ & \begin{tabular}{|c|} 
Benchmark \\
1
\end{tabular} & & Total \\
\hline Connecting, Synthesizing, \& Transforming & 100 & 27 & 21 & 6 & 0 & 154 \\
\hline CRITICAL THINKING VALUE RUBRIC & $\begin{array}{l}\text { Capstone } \\
4\end{array}$ & $\begin{array}{l}\text { Milestone } \\
3\end{array}$ & $\begin{array}{l}\text { Milestone } \\
2\end{array}$ & $\begin{array}{c}\text { Benchmark } \\
1\end{array}$ & & Total \\
\hline Critical Position-Taking & 90 & 33 & 25 & 6 & 0 & 154 \\
\hline ETHICAL REASONING VALUE RUBRIC & $\begin{array}{c}\text { Capstone } \\
4\end{array}$ & $\begin{array}{l}\text { Milestone } \\
3\end{array}$ & $\begin{array}{l}\text { Milestone } \\
2\end{array}$ & \begin{tabular}{|c|} 
Benchmark \\
1
\end{tabular} & & Total \\
\hline Ethical Awareness & 80 & 41 & 27 & 6 & 0 & 154 \\
\hline GLOBAL LEARNING VALUE RUBRIC & $\begin{array}{c}\text { Capstone } \\
4 \\
\end{array}$ & $\begin{array}{c}\text { Milestone } \\
3 \\
\end{array}$ & $\begin{array}{c}\text { Milestone } \\
2 \\
\end{array}$ & $\begin{array}{c}\text { Benchmark } \\
1 \\
\end{array}$ & & Total \\
\hline Personal \& Social Responsibility & 72 & 34 & 41 & 7 & 0 & 154 \\
\hline INFO LITERACY VALUE RUBRIC & $\begin{array}{c}\text { Capstone } \\
4 \\
\end{array}$ & $\begin{array}{c}\text { Milestone } \\
3 \\
\end{array}$ & $\begin{array}{c}\text { Milestone } \\
2 \\
\end{array}$ & \begin{tabular}{|c|} 
Benchmark \\
1 \\
\end{tabular} & & Total \\
\hline Use of Information to Accomplish Purpose & 92 & 23 & 33 & 6 & 0 & 154 \\
\hline INQUIRY \& ANALYSIS VALUE RUBRIC & $\begin{array}{c}\text { Capstone } \\
4 \\
\end{array}$ & $\begin{array}{c}\text { Milestone } \\
3 \\
\end{array}$ & $\begin{array}{c}\text { Milestone } \\
2 \\
\end{array}$ & $\begin{array}{c}\text { Benchmark } \\
1 \\
\end{array}$ & & Total \\
\hline Design Process & 99 & 17 & 32 & 6 & 0 & 154 \\
\hline INTEGRATIVE LEARNING VALUE RUBRIC & $\begin{array}{c}\text { Capstone } \\
4\end{array}$ & $\begin{array}{c}\text { Milestone } \\
3\end{array}$ & $\begin{array}{l}\text { Milestone } \\
2\end{array}$ & \begin{tabular}{|c|} 
Benchmark \\
1
\end{tabular} & & Total \\
\hline Connections to Experience & 103 & 15 & 30 & 6 & 0 & 154 \\
\hline INTERCULTURAL KNOWLEDGE RUBRIC & $\begin{array}{c}\text { Capstone } \\
4 \\
\end{array}$ & $\begin{array}{c}\text { Milestone } \\
3 \\
\end{array}$ & $\begin{array}{c}\text { Milestone } \\
2 \\
\end{array}$ & \begin{tabular}{|c|} 
Benchmark \\
1 \\
\end{tabular} & & Total \\
\hline Empathy & 81 & 30 & 36 & 7 & 0 & 154 \\
\hline LIFELONG LEARNING VALUE RUBRIC & $\begin{array}{c}\text { Capstone } \\
4 \\
\end{array}$ & $\begin{array}{c}\text { Milestone } \\
3 \\
\end{array}$ & $\begin{array}{c}\text { Milestone } \\
2 \\
\end{array}$ & $\begin{array}{c}\text { Benchmark } \\
1 \\
\end{array}$ & & Total \\
\hline Independent Learning & 100 & 13 & 34 & 7 & 0 & 154 \\
\hline ORAL COMMUNICATION RUBRIC & $\begin{array}{c}\text { Capstone } \\
4 \\
\end{array}$ & $\begin{array}{c}\text { Milestone } \\
3 \\
\end{array}$ & $\begin{array}{c}\text { Milestone } \\
2 \\
\end{array}$ & $\begin{array}{c}\text { Benchmark } \\
1 \\
\end{array}$ & & Total \\
\hline Communicating Central Message & 100 & 14 & 34 & 6 & 0 & 154 \\
\hline PROBLEM-SOLVING VALUE RUBRIC & $\begin{array}{c}\text { Capstone } \\
4\end{array}$ & $\begin{array}{c}\text { Milestone } \\
3\end{array}$ & $\begin{array}{l}\text { Milestone } \\
2\end{array}$ & \begin{tabular}{|c|} 
Benchmark \\
1
\end{tabular} & & Total \\
\hline Implementing a Solution & 81 & 35 & 32 & 6 & 0 & 154 \\
\hline QUANTITATIVE LITERACY RUBRIC & $\begin{array}{c}\text { Capstone } \\
4 \\
\end{array}$ & $\begin{array}{c}\text { Milestone } \\
3 \\
\end{array}$ & $\begin{array}{c}\text { Milestone } \\
2 \\
\end{array}$ & $\begin{array}{c}\text { Benchmark } \\
1 \\
\end{array}$ & & Total \\
\hline Communication & 65 & 27 & 55 & 7 & 0 & 154 \\
\hline READING VALUE RUBRIC & $\begin{array}{c}\text { Capstone } \\
4 \\
\end{array}$ & $\begin{array}{c}\text { Milestone } \\
3 \\
\end{array}$ & $\begin{array}{c}\text { Milestone } \\
2 \\
\end{array}$ & \begin{tabular}{|c|} 
Benchmark \\
1 \\
\end{tabular} & & Total \\
\hline Interpretation & 93 & 19 & 36 & 6 & 0 & 154 \\
\hline TEAMWORK VALUE RUBRIC & $\begin{array}{c}\text { Capstone } \\
4 \\
\end{array}$ & $\begin{array}{c}\text { Milestone } \\
3 \\
\end{array}$ & $\begin{array}{c}\text { Milestone } \\
2 \\
\end{array}$ & \begin{tabular}{|c|} 
Benchmark \\
1 \\
\end{tabular} & & Total \\
\hline Contributing to Team Meetings & 103 & 29 & 17 & 5 & 0 & 154 \\
\hline WRITTEN COMMUNICATION RUBRIC & $\begin{array}{l}\text { Capstone } \\
4\end{array}$ & $\begin{array}{l}\text { Milestone } \\
3\end{array}$ & $\begin{array}{l}\text { Milestone } \\
2\end{array}$ & \begin{tabular}{|c|} 
Benchmark \\
1
\end{tabular} & & Total \\
\hline Genre and Disciplinary Conventions & 82 & 35 & 31 & 6 & 0 & 154 \\
\hline
\end{tabular}

*AAC\&U refers to Association of American Colleges and Universities. Levels of student attainment range from "benchmark" to "capstone" with capstone being the highest level of student achievement.

** Total number of students assessed appears as "Total" on the right of each rubric.

***Numbers to right of "benchmark 1" are scores below benchmark criteria. 
sessment requirements related to the integration of UR into the curriculum. The added time required of faculty comes at a sacrifice of other duties. Therefore, presenting expectations to faculty and gaining their buy-in prior to beginning the process is very important. Our findings are limited to one university, and further research into the potential for success at other institutions should be examined.

By providing financial and logistical support, Georgia College \& State University's MURACE program has facilitated the expansion of mentored undergraduate research and creative endeavors, particularly at the curricular level, through planning and implementation grants. Over two years, the environmental science and theatre programs have restructured their curricula so that all their students participate in UR. Both programs created, redesigned, and enhanced courses, and both programs provided substantial support for students to present at state, regional, and national conferences. Many of the programs' students have produced original intellectual and creative works, and, as noted earlier, some students reported a direct link between their UR experiences and their success after graduation. The programs truly are models for scaffolding undergraduate research into the curriculum to reach the greatest numbers of undergraduates possible.

\section{References}

Americans for the Arts. 2016. "Shaping Federal Arts Policy: Big Year-End Victories in 2015." Arts Action News 1: 3.

Association of American Colleges and Universities. n.d. Value Rubrics. http:// www.aacu.org/value-rubrics.

Briggs, Charlotte L., Joan S. Stark, and Jean Rowland-Poplawski. 2003. "How Do We Know a 'Continuous Planning' Academic Program When We See One?" The Journal of Higher Education 74(4): 361-385. doi: 10.1353/ jhe.2003.0028.

Buller, Jeffrey L. 2012. The Essential Department Chair: A Comprehensive Desk Reference. San Francisco, CA: John Wiley \& Sons.

Lee, Virginia S., Michael R. Hyman, and Geraldine Luginbuhl. 2007. "The Concept of Readiness in the Academic Department: A Case Study of Undergraduate Education Reform." Innovative Higher Education 32(3): 3-18. doi: $10.1007 / \mathrm{s} 10755-006-9032-6$

Lopatto, David. 2007. "Undergraduate Research Experiences Support Science Career Decisions and Active Learning." CBE - Life Sciences Education 6(4): 297-306. doi: 10.1187/cbe.07-06-0039.

Maki, Peggy L. 2015. Assessment that Works: A National Call, a Twenty-First Century Response. Washington, DC: Association of American Colleges and Universities.

Russell, Susan H., Mary P. Hancock, and James McCullough. 2007. "Benefits of Undergraduate Research Experiences." Science 316(5824): 548-549. doi: 10.1126/science.1140384.
Saltmarsh, John, and Sherril Gelmon. 2006. "Characteristics of an Engaged Department: Design and Assessment." In Engaging Departments: Moving Faculty Cultures from Private to Public, Individual to Collective Focus for the Common Good, edited by Kevin Kecskes, 27-44. Boston: Anker.

Searight, H. Russell, Susan Ratwik, and Todd Smith. 2010. "Hey, I can do this! The Benefits of Conducting Undergraduate Psychology Research for Young Adult Development." Insight: Journal of Scholarly Teaching (5): 106-114.

Uchiyama, Kay Pippin, and Jean L. Radin. 2009. "Curriculum Mapping in Higher Education: A Vehicle for Collaboration." Innovation in High Education 33(4): 271-280. doi: 10.1007/s10755-008-9078-8.

Wergin, Jon F. 2003. Departments that Work: Building and Sustaining Cultures of Excellence in Academic Programs. Bolton, MA: Anker.

Zelenitsky, Sheryl, Laverne Vercaigne, Neal M. Davies, Christine Davis, Robert Renaud, and Cheryl Kristjanson. 2014. "Using Curriculum Mapping to Engage Faculty Members in the Analysis of a Pharmacy Program." American Journal of Pharmaceutical Education 78(7): 1-9. doi: 10.5688/ ajpe787139.

Zimbardi, Kirsten, and Paula Myatt. 2014. "Embedding Undergraduate Research Experiences Within the Curriculum: A Cross-Disciplinary Study of the Key Characteristics Guiding Implementation." Studies in Higher Education 39(2): 233-250. doi: 10.1080/03075079.2011.651448.

\section{Doreen Sams}

Georgia College \& State University, doreen.sams@gcsu.edu

Doreen Sams is a professor of marketing and coordinator of the Mentored Undergraduate Research and Creative Endeavor Faculty (MURACE) at Georgia College \& State University. She is a member of the editorial review board of the Journal of Marketing Theory and Practices and reviews articles and presentations for several other journals and conferences. She has published a book chapter and articles in several academic journals, as well as frequently presenting at conferences globally. She earned her PhD from the University of South Florida, Tampa.

Karen Berman is chair and artistic director of the Department of Theatre and Dance at Georgia College \& State University and a CUR At-Large Councilor. She is dean-elect of the prestigious College of Fellows of the American Theatre and has served as president of the Association for Theatre in Higher Education. She is co-artistic director of Washington Women in Theatre, and her social-change work includes theatrical productions with at-risk youth at Ballou High School in Washington, D.C., and Baldwin High School and Teen Scene Macon in Georgia. Her scholarly work includes an upcoming book chapter on "Transformative Education Processes: Difficult Dialogues and Global Citizenry." She has directed more than 100 productions in venues ranging from the Smithsonian Institution to off-Broadway and has written and directed several plays in the Czech Republic. Berman received her MFA from Catholic University of America and PhD from Capella University. 
Steven Jones is director of the Center for Faculty Development and associate professor of political science at Georgia College \& State University. He has written or edited several publications related to domestic and international civic engagement and is a co-editor, with Robert Bringle and Julie Hatcher, of International Service Learning: Conceptual Frameworks and Research. He edited the second edition of Campus Compact's Introduction to Service Learning Toolkit and is a co-author of two other Campus Compact monographs, The Community's College: Indicators of Engagement at Two-Year Institutions and The Promise of Partnerships: Tapping into the Campus as a Community Asset. He is also co-editor, with James Perry, of Quick Hits for Educating Citizens. His most recent publication is a book chapter in International Volunteer Tourism: Critical Reflections on Good Works in Central America. Jones received a PhD in political science from the University of Utah.

Amy Pinney is an associate professor in the Department of Theatre and Dance at Georgia College \& State University and co-chair of its Student Research Conference. She teaches courses in acting, directing, and theatre history and has published essays in Theatre Topics, Qualitative Inquiry, and Theatre Annual: A Journal of Performance Studies. Her research interests include performance ethnography, women in performance history, and performance pedagogy. She received her MA in theatre from the University of Missouri, Columbia, and her PhD in performance studies from Southern Illinois University, Carbondale.

Kalina Manoylov is an associate professor of biology at Georgia College \& State University and an adjunct associate professor at the University of Iowa. She uses algal-community data to understand environmental changes and anthropogenic effects in different aquatic environments. She has published more than 30 peerreviewed articles, half of them with her students. Manoylov was invited by the Journal of Phycology to summarize current uses of algal taxonomy for bioassessment. She is an editor of Phytokeys, an international journal of algal taxonomy and ecology. Manoylov has a PhD from Michigan State University.

Christine Mango Mutiti is a lecturer in the Department of Biological and Environmental Sciences at Georgia College \& State University. Her research interests are wetland, forest, and landscape ecology, including the application of remote sensing and Geographic Information Systems (GIS). She uses course-based undergraduate research in her upper-level courses in wetland and landscape ecology and also mentors undergraduates conducting independent research studies. She holds a PhD in botany and a masters in environmental sciences from Miami University and a $B S$ in agricultural science from the University of Nairobi, Kenya.

Samuel Mutiti is an associate professor at Georgia College \& State University, where he teaches courses in geology and environmental sciences and mentors undergraduate and graduate students in research. He is actively involved in efforts to expand high-quality undergraduate research at the university and in the environmental sciences curriculum via both independent research and coursebased research. His research group works on local and international research on water, soils, and environmental contamination and remediation. Mutiti holds a PhD in hydrogeology and a master's in environmental sciences from Miami University. He also has degrees from the University of Cambridge and the University of Wales, Cardiff.

Allison R. VandeVoort is an assistant professor in the Department of Biological and Environmental Sciences at Georgia College \& State University. She researches soil biogeochemistry and novel soil contaminants in agroecosystems. She mentors undergraduate researchers in and out of the classroom, particularly focusing on course-based, community-centered research in soil science. She holds a PhD in plant and environmental sciences from Clemson University and $a B S$ in biology and environmental science from St. Norbert College.

Caralyn B. Zehnder is an associate professor in Georgia College \& State University's Department of Biological and Environmental Sciences and is the coordinator of the environmental science program, where she has worked with colleagues to build opportunities for undergraduate research. Her research focuses on plant-insect interactions in both natural and agricultural settings. In 2014, Zehnder received the Georgia Colleges Excellence in Teaching Award. She holds a PhD in ecology from the University of Georgia and a BS in biology from Pennsylvania State University.

doi: $10.18833 /$ curq/37/1/2 